\title{
The Impact of Regulations and Technology on Corporate Social Responsibility Disclosures - Evidence from Maharatna Central Public Sector Enterprises in India
}

\author{
Prof. B. Charumathi ${ }^{1}$ and Padmaja Gaddam ${ }^{2}$
}

\begin{abstract}
Information technology (IT), being an effective fount for all types of business policies, is useful for executing any firm's Corporate Social Responsibility (CSR) initiatives. IT has advanced tools and applications to execute the business plans very effectively which can leave the lasting footprints on the society, and also be helpful in increasing profits, enhancing the workplace, creating transformations for the disabled employees, creating educational opportunities that can bridge the digital divide, improving the business ethics and helping the society. CSR has become an integral part of the organizations which are involving all their stakeholders as beneficiaries and India is the first country to have the mandated CSR regulations. The present study has made an attempt to study the impact of CSR Regulations and technology on the CSR disclosures of the Indian Central Public Sector Enterprises (CPSEs) having Maharatna Status. For this purpose, Corporate Social Responsibility Disclosure Index (CSRDI) developed by Charumathi \& Padmaja, 2015 was adopted for measuring the level of CSR disclosure and Corporate Information and Communication Technology Usage Index (CICTI) was developed and used to measure the level of IT usage. This study used secondary data. Using manual content analysis, the required data for (a) CSR Disclosures were collected from the annual reports of Maharatna companies and (b) CICT usage were collected from the web portals,

\footnotetext{
${ }^{1}$ Department of Management Studies, School of Management, Pondicherry University, (A Central University of Government of India), Pondicherry - 605 014, India.

${ }^{2}$ Ph.D. Research Scholar (UGC - SRF), Department of Management Studies, School of Management, Pondicherry University, Pondicherry - 605 01, India.
} 
recruitment portals, social media, news articles, CSR news by Maharatna companies and other digital sources. The sample for the study includes seven Maharatna CPSEs and the period of the study is six years ranging from 2011-12 to 2016-17. Using paired t test, it is found that there is a significant difference in CSR disclosures during pre and post-regulatory periods. CSR disclosures of Maharatna companies significantly increased post-CSR regulatory period. Using multiple regression analysis, it is found that there is a positive and significant relationship between the ICT usage and the CSR disclosures of Maharatna companies.

JEL Classification: M14, N70.

Keywords: Corporate Social Responsibility, CSR Disclosure Index, Information Communication Technology, Central Public Sector Enterprises, Maharatna Companies.

\section{INTRODUCTION}

Corporate Social Responsibility (CSR) is defined as the activities to improve social agenda beyond requirements. CSR has been a mainstream activity in business and has become an important public issue around the globe. Recently, society is also considering enterprises' contribution towards CSR, which tends to influence people's decisions when purchasing goods. Most of the works have explored CSR in advanced countries and only a small number of studies have been conducted in developing countries. India has a long tradition of companies contributing to the society in the name of philanthropy. India is the first country to enact mandatory CSR in parliament. By the passage of a revision to the Companies Act in 2013, companies must allocate at least $2 \%$ of their average net profit during the previous 3 years for CSR expenses. Business requires passable stratagems to achieve the full benefits of technology, through electronic commerce is an important path to conduct communications between the organizations and their customers (Lee \& Kim, 2007). As per the CSR theory, organizations have a commitment to society (Carroll, 1979, 1991, 1999). Organizations by adapting and implementing the IT into their management applications, they can have better relationships with all their stakeholders by doing CSR activities. Indian Central Public Sector Enterprises (CPSEs), to ensure welfare state of the society, are undertaking a lot of CSR initiatives such as education, health, community development and environment besides capacity building. Among the CPSEs, Indian Maharatna companies are more responsible towards their stakeholders.

\section{REVIEW OF LITERATURE}

\subsection{Regulations on CSR - International and National (India)}

Over the past few years, CSR has become important on the international stage and encountered many conceptual changes. New tools have been developed besides the updation and enhancement of existing ones. After the ISO 26000 Guidance on Social Responsibility was published in 2010, the updated OECD Guidelines for Multinational Enterprises and the UN Guiding Principles on Business and Human Rights were released in 2011. The UN Sustainable Development Goals of the 2030 Agenda for Sustainable Development, which appeared in 2015, 
also emphasises the contribution the private sector can make to sustainable development. OECD Guidelines help the companies to exercise their responsibility and apply in their operations. The OECD guidelines are not legally binding but the National Contact Points (NCPs) of the signatory States support their implementation. Any suspected breaches against the OECD guidelines can be reported to the NCPs, which offer a platform for dialogue or a mediation procedure. Sectorspecific guidelines (covering minerals, agriculture, textiles, finance, etc.) support the implementation of the OECD guidelines and enterprises' due diligence in particular.

UN Guiding Principles on Business and Human Rights include 31 principles and are based on three pillars: To protect the population from human rights abuses (e.g., laws, incentives and awareness raising), countries must take the necessary measures (State's duty). Enterprises shall respect human rights and exercise due diligence in proportion to the circumstances (Corporate Responsibility). Countries and enterprises have a responsibility to facilitate effective remediation for those affected by means of judicial and extrajudicial measures (Access to remedy). These principles are applicable to all countries and enterprises regardless of their size, sector, location, ownership, and organisational structures. However, they do not constitute international obligations.

United Nations Global Compact (UNGC) has offered an introduction to CSR issues and serves as a networking and learning platform with the help of its 10 universal principles on human rights, working standards, the environment and combating corruption. With more than 10,000 participating enterprises and organisations, it is now the biggest network in the world for responsible business conduct. The UNGC is a multi-stakeholder platform whose primary goal is to facilitate dialogue between the individual interest groups working together to implement the principles. Participating enterprises are obliged to publish a report on the progress they have made in implementing the principles each year.

ISO 26000 guidelines on Social Responsibility were elaborated as part of a broad-based international process between industry and developing countries, enterprises, workers, consumers and non-governmental organisations. It helps enterprises and organisations take a strategic approach to their business processes in accordance with responsible business conduct principles.

The recent G4 sustainability reporting guidelines developed by one of the internationally renowned institutions, viz., Global Reporting Initiative (GRI) are an encompassing framework that helps companies around the world to report their performance in terms of people, planet, and profit. The reporting framework covers principles and indicators for enterprises and other organisations to measure their economic, environmental and social performance. At the same time, a report oriented towards the GRI also provides interested groups with a transparent representation of the relevant sustainability aspects of an enterprise.

KPMG survey (2017), found that corporate reporting is the standard practice for the global large and mid-cap companies. Many of the worlds' biggest companies are integrating the financial and non-financial data in their annual reports. GRI remains the most popular international CSR standards for reporting. 
The stock market regulator Securities and Exchange Board of India (SEBI) also came up with the "National voluntary guidelines on social, economic and environmental responsibilities of business" under clause 55 of the listing agreement. These are the mandatory requirements for the top 100 companies of BSE and NSE listed as on $31^{\text {st }}$ March 2012. As per this, the companies have to disclose information about CSR expenditure, diversity of employees, grievance redressal mechanism and divulge the details on sustainable sourcing of products. This move clearly is an outcome of the increasing importance of CSR reporting.

In India, the revised CSR and sustainability guidelines issued by the Department of Public Enterprises (DPE) in Dec 2012 (effective from April 2013) played a crucial role. The revised guidelines have adjured the Central Public Sector Enterprises (CPSEs) to engage vigorously in CSR practices towards all the stakeholders and disclose its various CSR initiatives and performance to them. Earlier, CSR and sustainable development were dealt with differently for the purpose of a Memorandum of Understanding (MoU) evaluation. However, now they are combined into a single set of guidelines for greater transparency.

The budgetary allocation for CSR also stands modified. The CPSEs shall utilize the CSR budget which is allocated for CSR initiatives. If the CSR amount is unspent for the particular year, they should disclose the reasons for not utilizing the full amount and have to spend that amount in the next two financial years, failing which, it should be transferred to 'Sustainability Fund'. Currently, its implementation mechanism is being formulated separately. Loss-making or negative net worth companies got exempted from utilizing specific funds for CSR activities. However, they are expected to pursue the same by integrating them into their business processes. They can work in collaboration with other profit making CPSEs, in areas that do not require financial support.

In India, the Ministry of Corporate Affairs has conferred the Companies rules, 2014 under the Companies Act 2013 in which CSR, under the section 135, consists of the CSR policies, CSR Committee, Expenditure, Reporting and display of CSR activities in the concerned websites. In the revised guidelines, the impel of CSR and sustainability is evidently on capacity building, empowerment of communities, inclusive socio-economic growth, environmental protection, promotion of green and energy efficient technologies, development of backward regions, and upliftment of the marginalized and under-privileged sections of the society. The enacted mandatory CSR regulations in the Companies Act 2013 says that every company having net worth of rupees five hundred crore or more, or turnover of rupees one thousand crore or more or a net profit of rupees five crore or more during any financial year shall constitute a Corporate Social Responsibility Committee of the Board consisting three or more directors, out of which at least one director shall be an independent director, formulate the CSR policy which shall indicate the activities to be undertaken by the company as specified in Schedule VII and recommend the amount of expenditure to be incurred on the activities and disclose the CSR policy details, CSR activities, CSR amount spent in their websites and annual reports. The Board of every company shall ensure that the company spends, in every financial year, at least 2 percent of the average net profits of the company made during the three immediately preceding financial years, in pursuance of its Corporate Social Responsibility Policy. 


\subsection{Studies on the Development of CSR Disclosure Index (CSRDI) and ICT Usage Index}

Singh and Ahuja (1983) developed the CSRD Index consisting of 33 items by content analysis of 40 annual reports of top Indian public sector companies. Porwal and Sharma (1991) constructed an index with 8 items of community, environment, and HR for Indian Public and private sector companies. Hossain and Reaz (2007) constructed an index only with 18 items and the methodology used to measure the level of CSR Disclosures is sentence count for the Indian Bankex companies. Narwal (2007) constructed the CSR disclosure index of 21 items with no specific themes for the sample of 33 public and private sector banks in Haryana and found that CSR activities are mainly focused on education, balanced growth, health, environmental marketing and customer satisfaction. Murthy and Abeysekera (2008) measured the CSR Disclosures by counting the sentences of CSR activities disclosed in the annual reports and websites of 16 Top Indian software firms and found that the shortage of skilled labor in software companies in India might have led to CSR Disclosures in the area of Human Resources.

Sharma et al (2009) developed the CSRD index of 20 items with no specific themes for the sample of 50 Indian private companies and concluded that human capital is the main resource in development, determining the success of the organization, bears social responsibility for its action towards all stakeholders. Mustaruddin Saleh (2009) used the CSRDI of 20 items covering employee, community, product, and environment for the sample of 200 highest market capitalized public listed companies of Bursa Malaysia and concluded that environmental disclosures require much more attention from the Malaysian companies. Ramin Gamershlag et al (2010) developed the Environmental and social index of 32 items for the sample of 130 Listed German companies based on the GRI Guidelines. Rupal Tyagi (2010) measured the CSR disclosures based on the Environmental, Social, and Governance (ESG) scores of Indian companies given by CRISIL, S\&P, KLD for 215 Indian firms. Md Abdur Rouf (2011) developed the CSRD Index of 39 items for the Companies listed on Dhaka Stock Exchange. Uwuigbe et al (2011) constructed the CSRDI of 20 items, i.e., environment, energy, R\&D, employee health and safety for the 30 selected companies listed in Nigerian stock exchange market and found the significant association between the level of CSR disclosures and the corporate environmental visibility. Kansal and Singh (2012) constructed the Corporate Social Environment Energy Emission Index (CSEEE Index) consisting of 96 items with seven sub-themes for the sample of 82 top public listed companies and suggested that companies should focus more on the environment, emissions, product, safety innovations and alternative usage of energy.

Das (2013) measured the social reporting disclosures and HR disclosures, by using content analysis method, consisting of 19 items with four sub-themes for the sample of 26 Indian insurance companies and found that non-life insurance companies have disclosed less compared to insurance companies. Bhatia and Chander (2014) developed the CSRD index of 50 items for 25 BSE SENSEX companies and found that the leading companies are disclosing low in India and environment, community involvements are the well-disclosed areas. Kansal et al (2014) developed an index of 7 themes with 96 items including environment, energy, HR, carbon and greenhouse gas emission, community, product safety and innovation and measured the level of corporate social environment energy emission of BSE 100 companies. Nor Hawani et al (2015) developed the CSRD index consisting of 16 items based on human resource, marketplace, community, and environment for the sample of 44 government-linked companies listed in Bursa 
Malaysia and found that the theme of the disclosures shifted from human resources to marketplace.

Adams, Nelson and Todd (1992) measured the perceived usefulness, ease of use and usage of information technology based on primary data collected from the 118 respondents of 10 different organisations on two messaging technologies, viz., voice and electronic mails. Most of the respondents are using the electronic mail and ease of use is influencing the usage of IT. Stuart and Leitchy (1998) analysed a random sample of Fortune 500 companies and found that $90 \%$ had Web pages and $82 \%$ of the sites addressed at least one corporate social responsibility issue. More than half of the websites had items addressing community involvement, environmental concerns, and education. Few corporations, however, used their Web pages to monitor public opinion on issues or advocate policy positions. Oliner and Sichel (2000), drawing attention to the role of IT played, found that the growth of labour productivity recovered. Demand for the IT capital has remained vigorous which suggests that the growth contribution from using such capital has not fled from the historic high in 1999. Moreover, even if this contribution were to drop back a little in coming years, it would still be above the average in the second half of the 1990s.

\subsection{Studies on Impact of ICT usage on CSR Disclosures}

Oliner and Sichel (2011) described the role of IT in fulfilling the promise of corporate social responsibility. With the use of effective technology, organizations can focus effectively on the employee satisfaction, environmental protection and help the society. IT is the best enabler to take part in the business strategies. Mishra \& Srinivas Rao (2012) found that there is technological mapping in the improvement of innovative technology in the management process and $\mathrm{R} \& \mathrm{D}$ to improve the quality of the products and other technological improvements. Khandelawal and Bhakshi (2014) opined that as India has got newly implemented CSR Regulations, a lot of speculations are happening on the implementations and repercussions of the same.

Johnson and Brennan (2015) stated that technology plays a major role in CSR by accessing to the information and resulting in the increase of stakeholders' expectations which motivates the company to increase their CSR towards their stakeholders. Malaquias et al (2016) studied the effect of IT use on the business responsibility and developed a model based on the Carroll CSR theory which stated that Economical, Legal, Ethical and Discretionary are the responsibilities of the organizations. It was also found that there is a positive effect of IT use on the CSR activities of the business. Almazan, Tover and Quintero (2017) found that the companies that gives more attention to improving the quality of the system, information and information system improve their organizational results.

\section{RESEARCH GAP}

After the introduction of mandatory CSR regulations in India, CSR activities increased and in turn, the CSR related disclosures should have increased. To measure the level of CSR disclosures, few indices are available. Considering the nature of status and ownership of CPSEs, this study identified the CSRD Index for Maharatna CPSEs developed by Charumathi and Padmaja (2015) to measure the level of CSR Disclosure. As regards ICT usage by corporate, some studies have explored the impact of IT on the productivity, firm performance, 
organizational outcomes, and transformation. To the best knowledge of the authors, no comprehensive IT usage Index is available to measure the level of ICT usage by CPSEs. Further, the impact of CSR Regulations and ICT usage on CSR disclosures have not been studied. Hence, to fill these gaps, the present study has developed an original Corporate ICT Usage Index to measure the level of ICT usage by Maharatna CPSEs. Further, this study has developed one conceptual model as shown in fig. 1. By ICT usage, CPSEs can give more access to information, which increases the expectations of their stakeholders. To meet increased expectations, CPSEs have to a) carry out more CSR activities towards various stakeholders, viz., employees, customers, suppliers, community, environment and society and b) disclose information on CSR activities in their websites.

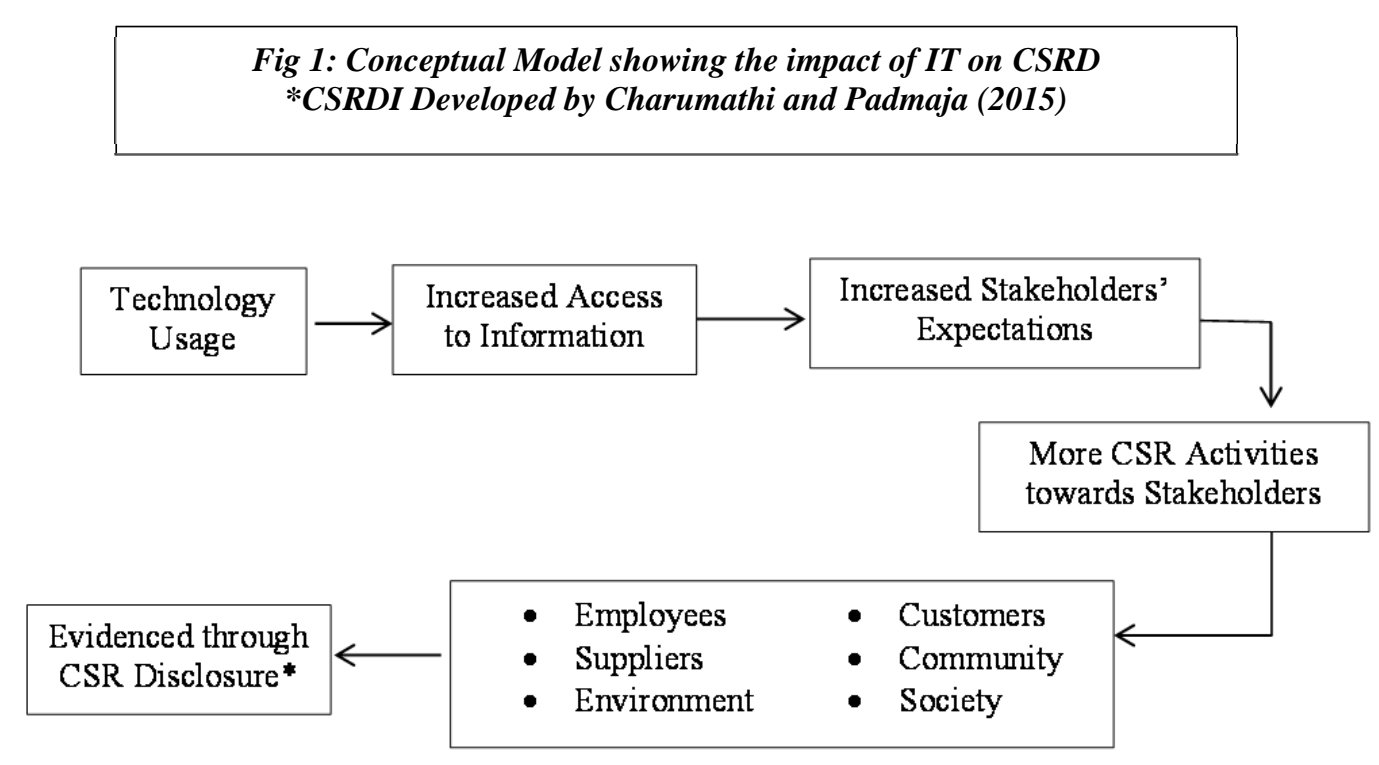

\section{STATEMENT OF THE PROBLEM}

Public Sector Enterprises (PSEs) have played a vital role to make India as one of the world's strongest emerging markets. To sustain this growth, CSR initiatives have become a pivotal part of the companies' strategic decision-making process. In order to integrate this into their business models and achieve the nation's aim of inclusive growth, the revised CSR and sustainability guidelines were issued by the Department of Public Enterprises (DPE) in Dec 2012 (effective from April 2013). In 2009, the Government established the Maharatna status for seven CPSEs, which have three years with an annual net profit of over Rs. 2,500 crores, net worth of Rs. 10,000 crore and turnover of Rs. 25,000 crore. The responsibility of Maharatna CPSEs is comparatively higher than the rest of the CPSEs in India. Hence, this study has been taken up to find whether the introduction of CSR regulations has increased the CSR activities and in turn improved the CSR disclosures by CPSEs in India. Further, as the ICT usage has led to increased access to information and stakeholders' expectations, CPSEs carryout more CSR activities and disclose the same in their reports. Hence, this study also attempts to analyse the impact of ICT usage on the CSR disclosure by Maharatna CPSEs in India. 


\section{OBJECTIVES OF THE STUDY}

Following are the objectives of the study:

1) To measure the level of CSR disclosure by Maharatna CPSEs in India using CSRDI developed by Charumathi and Padmaja (2015).

2) To develop an original Corporate Information, Communication Technology usage Index (CICTI) to measure the level of ICT usage by Maharatna CPSEs in India.

3) To analyse the impact of ICT usage on CSR disclosure by Maharatna CPSEs in India.

\section{HYPOTHESES}

$\mathbf{H}_{01}$ : There is no significant difference in the level of CSR disclosures by Maharatna CPSEs between pre and post introduction of CSR regulation.

$\mathbf{H}_{02}$ : There is no significant relationship between the ICT usage and CSR disclosures by Maharatna CPSEs during the study period.

$\mathbf{H}_{03}$ : There is no significant relationship between the CSR disclosures by Maharatna CPSEs and the usage of ICT for $\mathrm{H}_{03 a}$ : General and corporate communication, $\mathrm{H}_{03 b}$ : Marketing functions, $\mathrm{H}_{03 c}$ : Operations functions, $\mathrm{H}_{03 d}$ : Finance functions, $\mathrm{H}_{03 e}$ : Human resources functions and $\mathrm{H}_{03 f}$ : CSR activities during the study period.

\section{RESEARCH METHODOLOGY}

\subsection{Research Method}

This is an empirical study.

\subsection{Data - Nature, Source, and Method of Collection}

This study used secondary data. The required data relating to CSR Disclosure were collected from the annual reports and the sustainability reports from the official websites of Maharatna CPSEs. Besides, GRI regulations, the Companies Act, CSR Guidelines of DPE and SEBI, research papers, financial dailies, websites, etc. were also referred for collecting other required information. Data relating to ICT usage by CPSEs were collected from the web portals, recruitment portals, social media, news articles, CSR news by Maharatna companies and other digital sources. The method of data collection used is manual content analysis. Content analysis, a research technique is used for making replicable and valid inferences from data in their context (Krippendorff, 1980). 


\subsection{Sample}

The sample for this study is seven Indian Maharatna CPSEs, which are part of the BSE PSU Index. The companies include BHEL, CIL, GAIL, IOCL, NTPC, ONGC, SAIL as shown in Table 1. Their investment ceiling was raised from Rs. 1,000 crore to Rs. 5,000 crore. The Maharatna firms can now decide on investments up to $15 \%$ of their net worth in a project without explicit government approval.

\begin{tabular}{|c|l|l|}
\hline \multicolumn{3}{|c|}{ Table - 1 Details of Sample } \\
\hline S.No. & Maharatna Central Public Sector Enterprises in India \\
\hline 1 & BHEL & Bharat Heavy Electricals Limited \\
\hline 2 & CIL & Coal India Limited \\
\hline 3 & GAIL & Gas Authority of India Limited \\
\hline 4 & IOCL & Indian Oil Corporation Limited \\
\hline 5 & NTPC & National Thermal Power Corporation \\
\hline 6 & ONGC & Oil and Natural Gas Corporation \\
\hline 7 & SAIL & Steel Authority of India Limited \\
\hline
\end{tabular}

\subsection{Methodology \& Variables Used}

\subsubsection{Methodology for measuring CSR Disclosures and Variables used}

To assess the level of CSR disclosure by Maharatna CPSEs, this study adopted CSRD Index developed by Charumathi and Padmaja (2015) which was an original, comprehensive, unweighted (equal weighted) Index (CSRDI) consisting of seven variables. The variables of the index were arrived at after a thorough and rigorous study of the existing literature, regulatory framework and annual reports of the companies. Variables suggested by DPE guidelines for CSR activities of CPSEs are included in addition to other variables. The scores of CSR Disclosure Index were arrived by totaling the points secured by the various variables and converted into percentage terms to ensure equal weighting. Table 2 shows the variables used for constructing the CSR Disclosure Index. For more details, refer Corporate Social Responsibility Initiatives and Disclosure - Evidence From Maharatna Companies in India by Charumathi and Padmaja (2015). 


\begin{tabular}{|l|c|c|c|}
\hline \multicolumn{4}{|c|}{ Table 2 } \\
Variables used in the CSR Disclosure Index (CSRDI) for Maharatna CPSEs in India \\
\hline \multicolumn{1}{|c|}{ Disclosure on Sub-Indices } & $\begin{array}{c}\text { No. of } \\
\text { Variables }\end{array}$ & Score & $\begin{array}{c}\text { Score } \\
\text { (\%) }\end{array}$ \\
\hline Health Index (HI) & 21 & 21 & 100 \\
\hline Education Index (EI) & 22 & 22 & 100 \\
\hline Sanitation Index (SI) & 9 & 9 & 100 \\
\hline Environmental Sustainability Index (ESI) & 12 & 12 & 100 \\
\hline Rural Development Index (RDI) & 07 & 07 & 100 \\
\hline Community Development Index (CDI) & 24 & 24 & 100 \\
\hline Other Activities Index (OAI) & 06 & 06 & 100 \\
\hline Corporate Social Responsibility Disclosure Index & 101 & 101 & 100 \\
\hline Source: Constructed Charumathi and Padmaja, 2015. & & & \\
\hline
\end{tabular}

\subsubsection{Methodology for constructing Corporate Information and Communication Technology usage Index (CICTI) and Variables used}

As there was no single proxy/variable available for measuring ICT usage, this study has constructed an original, comprehensive, unweighted (equal weighted) Corporate Information and Communication Technology usage Index (CICTI) consisting of six variables. The variables were arrived at after a thorough and rigorous study of the existing literature and annual reports of the Maharatna CPSEs in India to understand the usage of ICT for different dimensions such as general corporate communication, marketing, operations, finance, human resources and CSR. A total of 64 variables were identified and an equal score of 1 was given if the item is disclosed or 0 otherwise. The scores of CICT Index were arrived by totaling the points secured by the various variables and converted into percentage terms to ensure equal weighting. The data for the CICTI were collected from the annual reports of the companies, web portals, recruitment portals, news articles, social websites like facebook, google plus, twitter, Pinterest, youtube, etc. Table 3 shows the variables used for constructing CICTI for Maharatna CPSEs in India. For more details, refer Annexure 1.

\begin{tabular}{|l|c|c|c|}
\hline \multicolumn{4}{|c|}{ Table 3 } \\
\multicolumn{4}{|c|}{$\begin{array}{l}\text { Variables used in Corporate Information and Communication Technology } \\
\text { Usage Index (CICTI)for Maharatna CPSEs in India }\end{array}$} \\
\hline \multicolumn{1}{|c|}{ Disclosure on Sub-Indices of CICTI } & $\begin{array}{c}\text { No. of } \\
\text { Variables }\end{array}$ & Score & $\begin{array}{c}\text { Score } \\
(\%)\end{array}$ \\
\hline $\begin{array}{l}\text { ICT usage for General and Corporate Communication } \\
\text { (GCC) }\end{array}$ & 12 & 12 & 100 \\
\hline ICT usage for Marketing Functions (MR) & 14 & 14 & 100 \\
\hline ICT usage for Operations Functions (OP) & 07 & 07 & 100 \\
\hline ICT usage for Finance Functions (FN) & 06 & 06 & 100 \\
\hline ICT usage for Human Resource Functions (HR) & 08 & 08 & 100 \\
\hline ICT usage for CSR activities (CSR) & 17 & 17 & 100 \\
\hline $\begin{array}{l}\text { Corporate Information and Communication Technology } \\
\text { Usage Index (CICTI) }\end{array}$ & 64 & 64 & 100 \\
\hline
\end{tabular}


Charumathi \& Padmaja | Impact of Regulations and Technology on Corporate Social Responsibility Disclosures

Note: Constructed by the authors.

\subsubsection{Control Variables}

The control variables such as Return on Capital Employed (as a measure of profitability) and the natural logarithm of Total Sales (as a proxy for size) are used in this study.

\subsection{Period of the study}

The period of the study is six years ranging from 2011-12 to 2016-17. To know the changes in the level of CSR disclosures before and after the introduction of CSR regulations, event methodology is used. The period of the study is divided into two groups consisting of 3 years each. From 2011-12 to 2013-14 are taken as the pre-regulation period and from 2014-15 to 2016-17 are taken as the post-regulation period. For analyzing the impact of ICT usage on CSR disclosure, the total period of 6 years is considered.

\subsection{Statistical Tools}

Descriptive analysis was done for understanding the data. Paired sample T-test is used to measure the level of CSR Disclosures during pre and post CSR Regulations. Multiple regression analysis is used to analyse the impact of ICT usage on the CSR disclosure of Maharatna CPSEs in India.

\subsection{Software used}

MS Excel and SPSS 20.0 are used for compiling and analyzing the data respectively.

\section{RESEARCH MODELS}

Following are the research models used in this study:

Model 1: CSRD Scores $=\beta_{0}+\beta_{1}$ CICTScores $+\beta_{2}$ Ln sales $+\beta_{3}$ ROCE $+\varepsilon_{\text {i }}$

Model 2: CSRD Scores $=\beta_{0}+\beta_{1} \mathrm{GCC}+\beta_{2} \mathrm{MR}+\beta_{3} \mathrm{OP}+\beta_{4} \mathrm{FN}+\beta_{5} \mathrm{CSR}+\beta_{6} \mathrm{HR}+\beta_{7} \mathrm{Ln}$ sales $+\beta_{8}$ $\mathrm{ROCE}+\varepsilon_{\mathrm{i}}$

Wherein, CSRD Scores arrived by using the CSRD Index is a dependent variable. Three independent variables considered in Model 1 include Corporate Information and Communication Technology Scores arrived by using the CICT Index, Return on Capital Employed, and Total Sales (Natural logarithm of Total Sales). In Model 2, eight independent variables are used. Six variables such as technology use for a) general and corporate communication, b) marketing functions, c) operations functions, d) finance functions, e) human resources functions, f) corporate social responsibility activities; and two control variables such as g) total sales and h) return on capital employed is used. 


\section{RESULTS AND DISCUSSIONS}

\subsection{Testing the Reliability of CSRDI and its Descriptive Statistics}

\begin{tabular}{|c|c|}
\hline \multicolumn{2}{|c|}{ Table 4} \\
Testing Reliability of CSRDI \\
\hline Cronbach's Alpha & .917 \\
\hline N of Items & $\mathbf{1 0 1}$ \\
\hline
\end{tabular}

Table 4 depicts the reliability statistics of the elements quoted in the Corporate Social Responsibility Disclosure Index of Maharatna CPSEs. The value of Cronbach's alpha is 0.917 and hence, the index is reliable.

\begin{tabular}{|c|c|c|c|c|}
\hline \multicolumn{5}{|c|}{ Table 5 } \\
Descriptive Statistics - Scores of CSRDI and its Sub-indices \\
\hline Index & Minimum & Maximum & Mean & SD \\
\hline HI & 10 & 95 & 46.71 & 20.803 \\
\hline EI & 41 & 41 & 40.91 & .000 \\
\hline SI & 0 & 89 & 46.83 & 22.696 \\
\hline ESI & 8 & 92 & 57.14 & 22.283 \\
\hline RDI & 0 & 100 & 63.61 & 24.684 \\
\hline CDI & 17 & 83 & 43.45 & 19.954 \\
\hline OAI & 0 & 100 & 40.08 & 29.462 \\
\hline CSRDI & 21 & 80 & 48.47 & 15.636 \\
\hline Valid N (listwise) & 42 & & & \\
\hline
\end{tabular}

Table 5 shows the descriptive statistics for scores of CSRDI and its sub-indices. From the mean values, it is clear that most of the Maharatna CPSEs are taking CSR initiatives and disclosing the same in the areas of rural development, other CSR activities, and health.

\subsection{Testing the Reliability of CICTI and its Descriptive Statistics}

\begin{tabular}{|c|c|}
\hline \multicolumn{2}{|c|}{ Table 6 } \\
Testing Reliability of CICTI \\
\hline Cronbach's Alpha & .845 \\
\hline N of Items & $\mathbf{6 4}$ \\
\hline
\end{tabular}


Table 6 depicts the reliability statistics of the elements quoted in the Corporate Information and Communication Technology Usage Index of Maharatna CPSEs. The value of Cronbach's alpha is 0.845 and hence, the index is reliable.

\begin{tabular}{|c|c|c|c|c|}
\hline \multicolumn{6}{|c|}{ Table 7 } \\
\multicolumn{6}{|c|}{ Descriptive Statistics - Scores of CICTI and its Sub-indices } \\
\hline Index & Minimum & Maximum & Mean & Std. Deviation \\
\hline GCC & 17 & 92 & 56.15 & 19.913 \\
\hline MR & 14 & 93 & 51.36 & 22.874 \\
\hline FN & 0 & 100 & 31.75 & 25.185 \\
\hline OP & 0 & 100 & 48.64 & 27.876 \\
\hline CSR & 41 & 82 & 61.20 & 13.253 \\
\hline HR & 13 & 100 & 62.20 & 25.675 \\
\hline TECH & 28 & 84 & 54.09 & 14.935 \\
\hline Valid N (listwise) & 42 & & & \\
\hline
\end{tabular}

Table 7 shows the descriptive statistics for scores of CICTI and its sub-indices. From the mean values, it is clear that most of the Maharatna CPSEs are using the ICT for finance functions, operations, human resources management and marketing functions.

\subsection{Results of Paired Sample T-Test}

\begin{tabular}{|c|c|c|c|c|c|c|c|c|}
\hline \multicolumn{9}{|c|}{$\begin{array}{c}\text { Table } 8 \\
\text { Results of Paired Sample T-Test }\end{array}$} \\
\hline \multirow{3}{*}{ Pair 1} & \multicolumn{5}{|c|}{ Paired Differences } & \multirow{3}{*}{$\mathrm{T}$} & \multirow{3}{*}{$\mathrm{df}$} & \multirow{3}{*}{ Sig. (2-tailed) } \\
\hline & \multirow{2}{*}{ Mean } & \multirow{2}{*}{$\begin{array}{c}\text { Std. } \\
\text { Deviation }\end{array}$} & \multirow{2}{*}{$\begin{array}{l}\text { Std. Error } \\
\text { Mean }\end{array}$} & \multicolumn{2}{|c|}{$\begin{array}{l}\text { 95\% Confidence Interval } \\
\text { of the Difference }\end{array}$} & & & \\
\hline & & & & Lower & Upper & & & \\
\hline $\begin{array}{l}\text { Pre RP- } \\
\text { Post RP }\end{array}$ & 25.271 & 10.158 & 2.217 & 20.647 & 29.895 & 11.400 & 20 & .000 \\
\hline
\end{tabular}

Note: Pre RP = Pre Regulatory Period; Post RP = Post Regulatory Period

Table 8 depicts the results of paired sample T-test for CSR disclosures of Maharatna CPSEs during pre and post-regulatory period. As the p-value is less than 0.01 , the null hypothesis, $\mathrm{H}_{01}$, is rejected at $1 \%$ level of significance. Hence, there is a significant difference in the level of CSR disclosures by Maharatna CPSEs between pre and post introduction of CSR regulation. The positive mean value indicates that there is a positive and significant increase in the level of CSR disclosures by Maharatna CPSEs during the post-regulatory period. 
AABFJ | Volume 12, no. 2, 2018

\subsection{Regression Results}

\begin{tabular}{|c|c|c|c|c|c|c|c|c|c|c|}
\hline \multicolumn{11}{|c|}{$\begin{array}{cc}\text { Table } 9 \\
\text { Regression Results - Impact of ICT usage on CSR Disclo }\end{array}$} \\
\hline \multicolumn{11}{|c|}{ Model Summary } \\
\hline Model & \multicolumn{10}{|c|}{\begin{tabular}{l|l} 
Adjusted R Square & Std. Error of the Estimate
\end{tabular}} \\
\hline 1 & $.936^{\mathrm{a}}$ & .876 & \multicolumn{3}{|c|}{.867} & \multicolumn{3}{|c|}{5.711} & \multicolumn{2}{|c|}{1.523} \\
\hline \multicolumn{11}{|c|}{ Analysis of Variance } \\
\hline \multicolumn{2}{|l|}{ Model } & \multirow{2}{*}{\multicolumn{3}{|c|}{$\begin{array}{c}\text { Sum of Squares } \\
8785.133 \\
\end{array}$}} & \multirow{2}{*}{$\begin{array}{c}\text { Df } \\
3\end{array}$} & \multirow{2}{*}{\multicolumn{2}{|c|}{$\begin{array}{c}\text { Mean Square } \\
2928.378\end{array}$}} & $\mathrm{~F}$ & \multicolumn{2}{|c|}{ Sig. } \\
\hline \multirow{3}{*}{1} & Regression & & & & & & & 89.793 & \multicolumn{2}{|c|}{$.000^{\mathrm{b}}$} \\
\hline & Residual & \multirow{2}{*}{\multicolumn{2}{|c|}{$\frac{1239.281}{10024.414}$}} & \multicolumn{2}{|c|}{38} & \multicolumn{2}{|c|}{32.613} & & & \\
\hline & Total & & & & & & & & & \\
\hline \multicolumn{11}{|c|}{ Coefficients } \\
\hline \multirow{2}{*}{\multicolumn{2}{|c|}{ Model }} & \multicolumn{3}{|c|}{$\begin{array}{l}\text { Unstandardized } \\
\text { Coefficients }\end{array}$} & $\begin{array}{l}\text { Stand } \\
\text { Coeff }\end{array}$ & $\begin{array}{l}\text { ardized } \\
\text { icients }\end{array}$ & \multirow[t]{2}{*}{$\mathrm{T}$} & \multirow[t]{2}{*}{ Sig. } & \multicolumn{2}{|c|}{ Collinearity Statistics } \\
\hline & & $\mathrm{B}$ & & d. Error & & eta & & & Tolerance & VIF \\
\hline \multirow{4}{*}{1} & (Constant) & 2.264 & & 2.013 & & & .188 & .852 & & \\
\hline & CICT Scores & .978 & & .062 & & 34 & 15.850 & .000 & .937 & 1.067 \\
\hline & ROCE & .007 & & .065 & & 10 & .103 & .918 & .371 & 2.695 \\
\hline & Ln Sales & -1.215 & & 1.781 & & 63 & -.682 & .499 & .379 & 2.639 \\
\hline \multicolumn{11}{|c|}{ Residual Statistics } \\
\hline & & \multirow{2}{*}{\multicolumn{2}{|c|}{$\begin{array}{c}\text { Minimum } \\
22.72\end{array}$}} & Maximum & & Mean & \multicolumn{3}{|c|}{ Std. Deviation } & $\mathrm{N}$ \\
\hline \multicolumn{2}{|c|}{ Predicted Value } & & & 78.11 & & 8.47 & \multicolumn{3}{|c|}{14.638} & 42 \\
\hline & Residual & -14.12 & & 12.982 & & .000 & & 5.498 & & 42 \\
\hline Std. P & Predicted Value & -1.75 & & 2.025 & & .000 & & 1.000 & & 42 \\
\hline & td. Residual & -2.47 & & 2.273 & & .000 & & .963 & & 42 \\
\hline
\end{tabular}

Table 9 shows the regression results for Model 1. The model summary shows that the R-Square is $87.6 \%$ and the adjusted R-Square is 86.7 . This means that $86.7 \%$ of the changes in the dependent variable (CSRD) are due to the variations of the independent variables used in this model, besides supporting the appropriate selection of proxies. By using the analysis of variance, it is found that $\mathrm{F}$ test of the model is significant at $1 \%$ level. The Durbin-Watson statistic for the model is substantially less than 2 which shows the evidence of positive correlation.

From the coefficients of the model, it is clear that there is a positive relationship between the technology used and corporate social responsibility disclosure by the Maharatna CPSEs. The Beta coefficient for the Technology is positive and significant with a P-Value of 0.000 . Hence, the null hypothesis, $\mathrm{H}_{02}$, is rejected at $1 \%$ level of significance. Thus, there is a significant positive relationship between the ICT usage and CSR disclosure of Maharatna companies. Thus, it can be concluded that the companies with the use of ICT tend to undertake more CSR activities which in turn lead to more CSR disclosures. However, there is no significant relationship between the CSR disclosure and the control variables such as size (Natural Logarithm of Sales) and profitability (in terms of Return on Capital Employed). The variance inflation factor (VIF) values for LnSales, CICT scores, ROCE are less than 5, which shows the non - existence of multicollinearity among the independent variables. 
Charumathi \& Padmaja | Impact of Regulations and Technology on Corporate Social Responsibility Disclosures

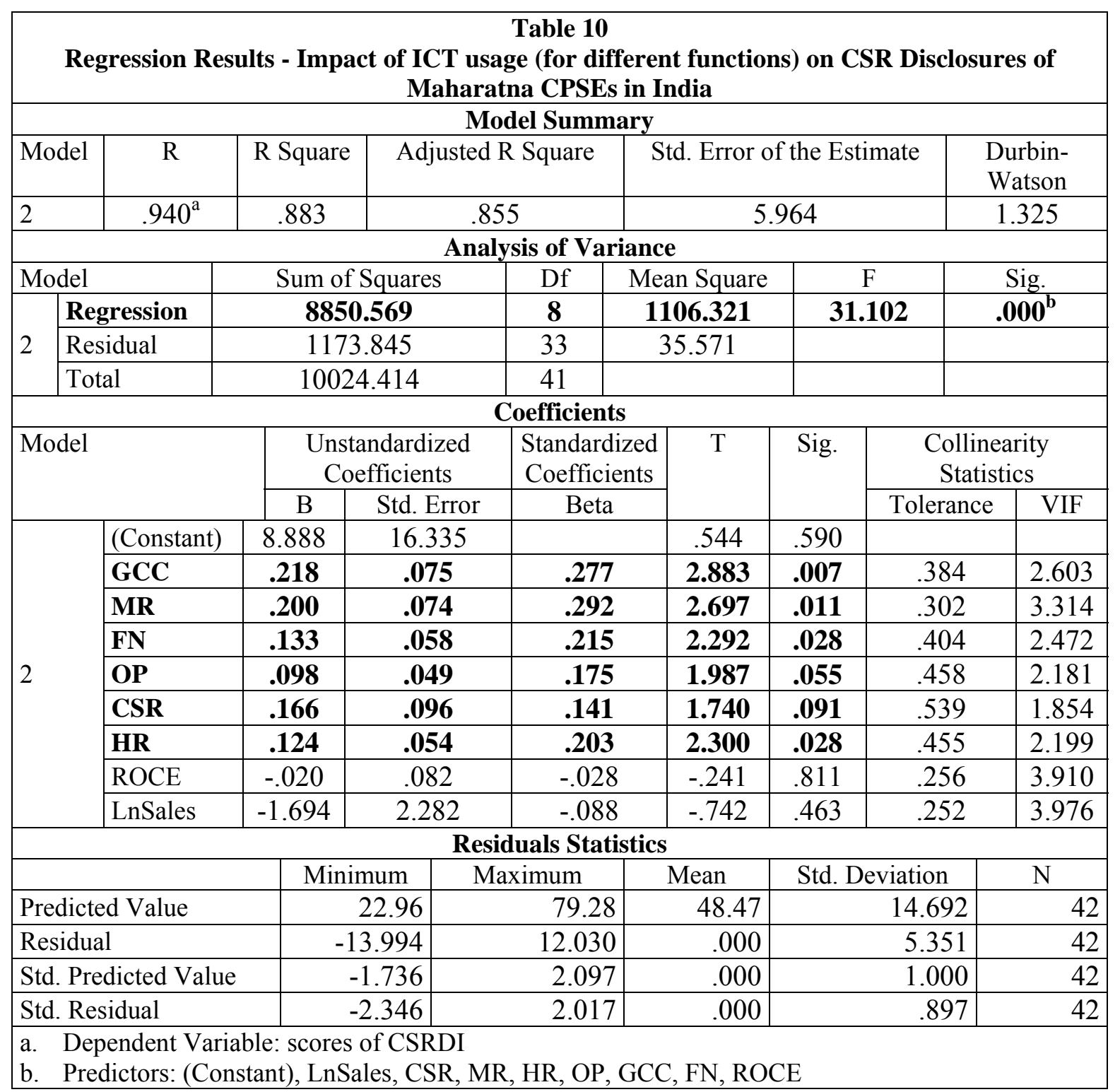

Table 10 shows the regression results for Model 2. The model summary shows that the RSquare is $88.3 \%$ and the adjusted R-Square is 85.5 . This means that $85.5 \%$ of the changes in the dependent variable (CSRD) are due to the variations of the independent variables used in this model, besides supporting the appropriate selection of proxies. By using the analysis of variance, it is found that $\mathrm{F}$ test of the model is significant at $1 \%$ level. The Durbin-Watson statistic for the model is substantially less than 2 which shows the evidence of positive correlation.

From the coefficients of the model, it is clear that there is a positive relationship between the CSR disclosure and usage of ICT for a) General and corporate communication; b) Marketing functions; c) Operations functions; d) Finance functions; e) Human Resource functions, and f) CSR activities. The coefficient of the variable ICT usage for general and corporate communication (GCC) is positive and significant at $1 \%$ level. Hence, the null hypothesis, $\mathrm{H}_{03 \mathrm{a}}$, is 
rejected at $1 \%$ level of significance. The coefficients of the variables such as ICT usage for marketing, finance, and human resource functions are positive and significant at $5 \%$ level. Hence, the null hypotheses, $\mathrm{H}_{03 \mathrm{~b}}, \mathrm{H}_{03 \mathrm{c}}$, and $\mathrm{H}_{03 \mathrm{f}}$ are rejected at $5 \%$ level of significance. The coefficients of the variables such as ICT usage for operations and CSR activities are positive and significant at $10 \%$ level. Hence, the null hypotheses, $\mathrm{H}_{03 \mathrm{~d}}$ and $\mathrm{H}_{03 \mathrm{e}}$ are rejected at $10 \%$ level of significance. Thus, there is a positive and significant relationship between the CSR disclosures by Maharatna CPSEs and the usage of ICT for $\mathrm{H}_{03 \mathrm{a}}$ : General and corporate communication, $\mathrm{H}_{03 \mathrm{~b}}$ : Marketing functions, $\mathrm{H}_{03 \mathrm{c}}$ : Operations functions, $\mathrm{H}_{03 \mathrm{~d}}$ : Finance functions, $\mathrm{H}_{03 \mathrm{e}}$ : Human resources functions and $\mathrm{H}_{03 \mathrm{f}}$ : CSR activities during the study period. Thus, it can be concluded that the ICT usage for various functions such as general \& corporate communication, marketing, finance, operations, human resources and CSR activities usher the companies to carry out more CSR activities which in turn lead to more CSR disclosures. However, there is no significant relationship between the CSR disclosure and the control variables such as size (Natural Logarithm of Sales) and profitability (in terms of Return on Capital Employed). The variance inflation factor (VIF) values for GCC, MR, FN, OP, CSR, HR, ROCE, LnSales are less than 5 which shows the non-existence of multicollinearity among the independent variables.

The residual statistics of model 1 and 2 consists of the standardized and unstandardized predicted and residuals values. Standardized values have a mean of 0 and a standard deviation of 1 show that the residuals are normally distributed and there are no outliers of influential data points. This study also tested the assumptions of the linear multiple regression model, viz., multicollinearity and homoscedasticity. None of the two independent variables are highly correlated and hence, there is no multicollinearity problem exists.

\section{LIMITATIONS OF THE STUDY}

1) The limitations of secondary data are applicable to this study.

2) Findings cannot be generalized and the same may not be true for private sector companies.

\section{IMPLICATIONS OF THE STUDY}

1) By using the CSRD Index adopted in this study, companies can measure the level of CSR disclosures. Thus, companies which carry out more CSR activities but disclosed less can improve themselves.

2) By using the CICT index developed by this study, companies can measure the level of ICT usage for various activities and know where they stand.

3) From this study, companies can understand the positive impact of usage of ICT for various functions and try to improve upon further where they are lacking.

4) The guidelines of the regulatory authority (DPE) basically suggested seven areas of CSR activities for CPSEs. As this study has taken more variables from the stakeholder's perspective, the regulators can think of bringing those additional areas of CSR into the mainstream.

\section{SCOPE FOR FUTURE RESEARCH}


1) This study used two indices such as the CSRD Index and CICT Index to measure the level of CSR disclosures and ICT usage by Maharatna CPSEs. Future academic researchers can try the same for other public sector enterprises besides Navratna and Miniratna CPSEs.

2) This study has developed an index to measure the level of ICT usage for various functions including CSR activities and analysed its impact on CSR disclosures of CPSEs. Future studies can develop an index to measure the level of ICT usage exclusively for CSR related activities and analyse the impact of the same on various dimensions.

\section{CONCLUSION}

CSR has become an integral part of the organizations which are involving all their stakeholders as beneficiaries and India is the first country to have the mandated CSR regulations. Information technology (IT), being an effective fount for all types of business policies, is useful for executing any firm's Corporate Social Responsibility (CSR) initiatives. IT has advanced tools and applications to execute the business plans very effectively which can leave the lasting footprints on the society, and also be helpful in increasing profits, enhancing the workplace, creating transformations for the disabled employees, creating educational opportunities that can bridge the digital divide, improving the business ethics and helping the society. This study found that the introduction of mandated regulations compelled the Maharatna CPSEs to increase CSR activities which in turn led to more CSR disclosures. Further, the ICT usage for various functions including CSR activities has had a significant positive impact on the CSR disclosures. Thus, Maharatna CPSEs can penetrate more on the usage of ICT for serving the stakeholders than ever before.

\section{References}

Aparna Bhatia and Subhash Chander (2014). Corporate Social Responsibility Disclosure by SENSEX Companies in India. Management and Labour Studies, 39(1), 1-17. https://doi.org/10.1177/0258042X14535161

Carroll, A. B. (1979). A three-dimensional conceptual model of corporate performance. The Academy of Management Review, 4(4), 497e505.

https://doi.org/10.5465/amr.1979.4498296

Carroll, A. B. (1991). The pyramid of corporate social responsibility: toward the moral management of organizational stakeholders. Business Horizons (July- August). https://doi.org/10.1016/0007-6813(91)90005-G

Carroll, A. B. (1999). Corporate social responsibility: evolution of a definitional construct. Business \& Society, 38(3), 268e295. https://doi.org/10.1177/000765039903800303

Charumathi, B. and Padmaja Gaddam (2015). Corporate Social Responsibility Initiatives and Disclosure - Evidence From Maharatna Companies in India. Indian Journal of Research, 5(2), 3-18. Retrieved from http://publications.rdaindia.net/?q. 
Companies Act CSR. (2013). Implications of Companies Act, 2013 Corporate Social Responsibility, The Companies Act, 2013 : An overview, (2277), 2013-2014.

Demian Abrego Almazán, Yesenia Sánchez Tovar,José M. Medina Quintero (2017). Influence of information systems on organizational results. Contaduría Y Administración, 62(2), 321-338. https://doi.org/10.1016/j.cya.2017.03.001

Dennis A. Adams, R. Ryan Nelson and Peter A. Todd. (2018). Perceived Usefulness, Ease of Use, and Usage of Information Technology : A Replication, 16(2), 227-247.

Department of Public Enterprises. (2012). DPE CSR guidelines. Retrieved September 12, 2012, from http://www.dpe.nic.in/important_links/dpe_guidelines.

Gamerschlag Ramin, Möller, K., and Verbeeten, F. (2011). Determinants of voluntary CSR disclosure: Empirical evidence from Germany. Review of Managerial Science, 5(2), 233262. https://doi.org/10.1007/s11846-010-0052-3.

Global Reporting Initiatives Reporting Principles and Standard Disclosures (2018) Available at: https://www.globalreporting.org/resourcelibrary/GRIG4-Part1-Reporting-Principles-andStandard-Disclosures.pdf.

SEBI, (Securities and Exchange Board of India), National Voluntary Guidelines (2012) Available at: https://www.sebi.gov.in/sebi_data/attachdocs/1344915990072.pdf.

Business \& Human Rights Resource Centre, Available at: https://www.businesshumanrights.org/en/un-guiding-principles.

United Nations Global Compact, (2018) UN Global Compact Announces New Board Members Appointed by the UN Secretary - General, Available at: https://www.unglobalcompact.org/.

ISO (International Organization for Standardization), (2018), ISO 26000 - Social responsibility, available at: https://www.iso.org/iso-26000-social-responsibility.html.

KPMG, (2017), The Road Ahead The KPMG Survey of Corporate Responsibility Reporting 2017 Available at: https://assets.kpmg.com/content/dam/kpmg/xx/pdf/2017/10/kpmg-survey-ofcorporate-responsibility-reporting-2017.pdf.

Hossain, M. and Reaz, M. (2007), The determinants and characteristics of voluntary disclosure by Indian banking companies. Corp. Soc. Responsib. Environ. Mgmt, 14: 274-288. https://doi.org/10.1002/csr.154

Kansal, M and Singh, S. (2012). Measurement of corporate social performance: an Indian perspective. Social Responsibility Journal, 8(4), 527-546. https://doi.org/10.1108/17471111211272101. 
Charumathi \& Padmaja | Impact of Regulations and Technology on Corporate Social Responsibility Disclosures

Kansal, M., Joshi, M., and Batra, G. S. (2014). Determinants of corporate social responsibility disclosures: Evidence from India. Advances in Accounting, 30(1), 217-229. https://doi.org/10.1016/j.adiac.2014.03.009.

Khandelwal, M. R., and Bakshi, M. S. (2014). The New CSR Regulation in India: The Way Forward. Procedia Economics and Finance, 11(14), 60-67. https://doi.org/10.1016/S2212-5671(14)00176-2.

Krippendorff, K. (1980). Content Analysis: An Introduction to its methodology. Beverly Hills, CA: Sage.

Lee, S., and Kim, K.-J. (2007). Factors affecting the implementation success of Internet based information systems. Computers in Human Behavior, 23, 1853e1880.

https://doi.org/10.1016/j.chb.2005.12.001

Malaquias, R. F., Malaquias, F. F. O., and Hwang, Y. (2016). Effects of information technology on corporate social responsibility: Empirical evidence from an emerging economy. Computers in Human Behavior, 59, 195-201. https://doi.org/10.1016/j.chb.2016.02.009.

Mishra, R. K., and Kolluru, S. (2011). Technology Mapping in Indian Central Public Sector Enterprises: Challenges of Heightened Competition Technology Mapping of Indian Central Public Sector Enterprises: Challenges of Heightened Competition. Institute of Public Enterprises, 1(1), 41-46. Retrieved from http://www.researchgate.net/publication/215834716.

Murthy, V., and Abeysekera, I. (2008). Corporate social reporting practices of top Indian software firms. The Australasian Accounting Business \& Finance Journal, 2(1), 36-59.

Narwal, Mahabir. (2007), "CSR initiatives of Indian banking industry", Social Responsibility Journal, Vol.3 (4), pp. 49-60. https://doi.org/10.1108/17471110710840233

Nor Hawani Wan Abd Rahman, Mustaffa Mohamed Zain, Norashfah Hanim Yaakop Yahaya Al-Haj, (2011) "CSR disclosures and its determinants: evidence from Malaysian government link companies", Social Responsibility Journal, Vol. 7 Issue: 2, pp.181- 201, https://doi.org/10.1108/17471111111141486.

OECD Guidelines for Multinational Enterprises 2011. (2011). http://www.oecd.org/daf/inv/mne/48004323.pdf/.

Oliner, S. D., and Sichel, D. E. (2000). The Resurgence of Growth in the Late 1990s: Is Information Technology the, 14(4), 3-22.

Patil, V., and Sharma, S. (2009). Corporate social responsibility and human rights, 3(January 2014), 7-11. https://doi.org/10.15587/2313-8416.2015.38672.

Porwal, L. S. and Sharma, N. (1991), "Social Responsibility Disclosure by Indian Companies", The Chartered Accountant (India), Vol. XXXIX, No 8, p. 630-634. 
Rouf, M. A. (2011). The Corporate Social responsibility Disclosure: A Study of Listed Companies in Bangladesh. Business and Economics Research Journal, 2(3), 19-32. Retrieved from www.berjournal.com.

Salb, D., Friedman, H. H., \& Friedman, L. W. (2011). The Role of Information Technology in Fulfilling the Promise of Corporate Social Responsibility. Computer and Information Science, 4(4), 2-9. https://doi.org/10.5539/cis.v4n4p2.

Saleh, M. (2009). Corporate Social Responsibility Disclosure in an Emerging Market: A Longitudinal Analysis Approach. International Business Research, 2(1), 131-141. https://doi.org/10.5539/ibr.v2n1p131

Singh DR, Ahuja JM. 1983. Corporate social reporting in India. International Journal of Accounting 18(2): 151- 169.

Stuart L. Esrock, Greg B. Leichty (Autumn 1998) Social responsibility and corporate web pages: Self-presentation or agenda-setting? Public Relations Review, 24(3), 305-319. https://doi.org/10.1016/S0363-8111(99)80142-8.

Sudhir C. Das, (2013) "Corporate social reporting and human resource disclosures: experiences from insurance companies in India", Social Responsibility Journal, Vol. 9 Issue: 1, pp.19-32, https://doi.org/10.1108/17471111311307796.

Tyagi, R. (2012). Impact Of Corporate Social Responsibility On Financial Performance And Competitiveness Of Business: A Study Of Indian Firms Impact Of Corporate Social Responsibility On Financial Performance And Competitiveness Of Business : A Study Of Indian Firms, 667.

Uwuigbe, Uwalomwa, Olubukunola, and Ajayi, A. O. (2011). Corporate Social Responsibility Disclosures by Environmentally Visible Corporations: A Study of Selected Firms in Nigeria. European Journal of Business and Management, 3(9), 9-17. Retrieved from www.iiste.org.

Johnson, VE and Brennan, L, "Examining the impact of technology on social responsibility practices" In Re-Imaging Business Ethics: Meaningful Solutions for a Global Economy. Published online: 08 Mar 2015; 107-123. https://doi.org/10.1016/S1529-2096(02)04007$\underline{5 .}$ 
Charumathi \& Padmaja | Impact of Regulations and Technology on Corporate Social Responsibility Disclosures

\begin{tabular}{|c|c|c|}
\hline \multicolumn{3}{|c|}{$\begin{array}{ll}\text { Annexure 1 } \\
\end{array}$} \\
\hline \multicolumn{3}{|c|}{ Corporate Information and Communication Technology Usage Index (CICTI) } \\
\hline S.No. & Sub-Indices and its Variables & Weightage \\
\hline \multicolumn{3}{|c|}{ I. ICT Usage for General and corporate communication } \\
\hline 1 & Maintaining Website or web portals with all the information & 1 \\
\hline 2 & $\begin{array}{l}\text { Communication technology tools like electronic mail, mobile phones, and text } \\
\text { messaging services, social networks to engage and collect relevant information }\end{array}$ & 1 \\
\hline 3 & $\begin{array}{l}\text { Teleconference calls to make sure team members in different locations are on the } \\
\text { same page. }\end{array}$ & 1 \\
\hline 4 & Holding a webinar or web conference for travel-free face-to-face time & 1 \\
\hline 5 & Sharing of files and data with the cloud & 1 \\
\hline 6 & Intranet for local file sharing & 1 \\
\hline 7 & Use of instant messaging & 1 \\
\hline 8 & Mobile office that allows you to work productively from anywhere. & 1 \\
\hline 9 & Use remote desktop applications to access files on your office computer & 1 \\
\hline 10 & Go paperless to save money on supplies and storage in office & 1 \\
\hline 11 & Virtual phone number and an electronic fax line that you can take anywhere & \\
\hline 12 & $\begin{array}{l}\text { Customer data and information using information technology tools like websites } \\
\text { cookies and online surveys }\end{array}$ & 1 \\
\hline \multicolumn{3}{|c|}{ II. ICT Usage for Marketing Functions } \\
\hline 1 & $\begin{array}{l}\text { Use of technology to simplify the way customers pay for services or products. If } \\
\text { service or product can be ordered online, provide multiple ways of payment via } \\
\text { website }\end{array}$ & 1 \\
\hline 2 & $\begin{array}{l}\text { Use of electronic mail to notify customers about new deals and discounts, this will } \\
\text { make customers feel cared for and it will drive them to buy }\end{array}$ & 1 \\
\hline 3 & An online marketing plan that you be edited, update and share with the team. & 1 \\
\hline 4 & $\begin{array}{l}\text { Use of social media sites like Facebook, Twitter, Google+, Pinterest, YouTube, } \\
\text { etc. to promote your business, products and services }\end{array}$ & 1 \\
\hline 5 & Blog related to business and target audience. & 1 \\
\hline
\end{tabular}


AABFJ | Volume 12, no. 2, 2018

\begin{tabular}{|c|c|c|}
\hline 6 & Collecting email addresses through an opt-in form to have email marketing & 1 \\
\hline 7 & Video marketing & 1 \\
\hline 8 & Promoting business with a website and/or online advertising & 1 \\
\hline 9 & Use of Mailchimp to Easy product launch & 1 \\
\hline 10 & $\begin{array}{l}\text { Survey to get feedback from social networks by providing gift cards to get a quick } \\
\text { response }\end{array}$ & 1 \\
\hline 11 & Use social media to conduct customer service. & 1 \\
\hline 12 & Online help desk or ticket system to handle customer issues & 1 \\
\hline 13 & Allowing clients to schedule appointments online at their convenience. & 1 \\
\hline 14 & Use online surveys and questionnaires to get customer feedback & 1 \\
\hline \multicolumn{3}{|c|}{ III. $\quad$ ICT Usage for Operations functions } \\
\hline 1 & Time tracking software to become more productive. & 1 \\
\hline 2 & Explore open source applications to replace some of the best brand alternatives & 1 \\
\hline 3 & Streamlining of work processes with digital dictation & 1 \\
\hline 4 & $\begin{array}{l}\text { Project management and task management tools to stay on top of daily business } \\
\text { responsibilities. }\end{array}$ & 1 \\
\hline 5 & Digital filing system to make it easier to sort, save, share and find documents & 1 \\
\hline 6 & Email management process & 1 \\
\hline 7 & Production Automation process & 1 \\
\hline \multicolumn{3}{|c|}{ IV. $\quad$ ICT Usage for Finance Functions } \\
\hline 1 & Online invoicing service to reduce the costs of collecting payment from customers & 1 \\
\hline 2 & Online budget tracking & 1 \\
\hline 3 & Filing taxes online more efficiently & 1 \\
\hline 4 & Income stream by selling products online & 1 \\
\hline 5 & Use of comprehensive accounting software to streamline business finances & 1 \\
\hline 6 & $\begin{array}{l}\text { Sharing of digital files with bookkeeper or accountant to improve ongoing } \\
\text { bookkeeping processes }\end{array}$ & 1 \\
\hline
\end{tabular}


Charumathi \& Padmaja | Impact of Regulations and Technology on Corporate Social Responsibility Disclosures

\begin{tabular}{|c|c|c|}
\hline \multicolumn{3}{|c|}{ V. ICT Usage for Human Resources functions } \\
\hline 1 & e-recruitment web portals & 1 \\
\hline 2 & Postings regarding recruitment in web and social media & 1 \\
\hline 3 & Use of integrated video services to help the applicants in job portals & 1 \\
\hline 4 & Technology to train employees & 1 \\
\hline 5 & Virtual Manpower & 1 \\
\hline 6 & Assigning of New tasks to new employees for testing & 1 \\
\hline 7 & Use of technology to monitor the performance and behavior of employees & 1 \\
\hline 8 & Expansion of knowledge with online business training & 1 \\
\hline \multicolumn{3}{|c|}{ VI. ICT Usage for Corporate Social Responsibility activities } \\
\hline 1 & Technology to improve innovation in business & 1 \\
\hline 2 & Recycling of IT Resources & 1 \\
\hline 3 & Carbon Reduction & 1 \\
\hline 4 & Energy saving by the usage of Solar Power & 1 \\
\hline 5 & Maintaining Employee satisfaction by the concept of Learning organization & 1 \\
\hline 6 & Use of IT to provide education to the underprivileged students & 1 \\
\hline 7 & Providing Training and computer education to the unemployed & 1 \\
\hline 8 & Online supplier Registration portal & 1 \\
\hline 9 & Use of technology to produce Products with environmental concerns & 1 \\
\hline 10 & Innovative Technology in product development & 1 \\
\hline 11 & Portals relating to CSR News and Activities & 1 \\
\hline 12 & $\begin{array}{l}\text { Use of technology to coordinate with the hospitals and related sources to help the } \\
\text { society in maintaining primary health }\end{array}$ & 1 \\
\hline 13 & Use of technology to maintain sanitation & 1 \\
\hline 14 & $\begin{array}{l}\text { Introducing new technologies and tools to provide food and nutrition to eradicate } \\
\text { the hunger and malnutrition }\end{array}$ & 1 \\
\hline 15 & Use of technology to spread the information regarding the CSR to the villagers & 1 \\
\hline
\end{tabular}


AABFJ | Volume 12, no. 2, 2018

\begin{tabular}{|c|l|c|}
\hline 16 & Technology to provide the water resources to the remote villages & 1 \\
\hline 17 & Maintaining better pollution free environment with the use of technology & 1 \\
\hline \multicolumn{2}{|l|}{ Corporate Information Communication Technology Usage Index (CICTI) } & 64 \\
\hline
\end{tabular}

